\title{
Fresh and hardened properties of self-compacting concrete modified with lightweight and recycled aggregates
}

\section{Propriedades no estado fresco e endurecido do concreto autoadensável modificado com agregados leves e reciclados}
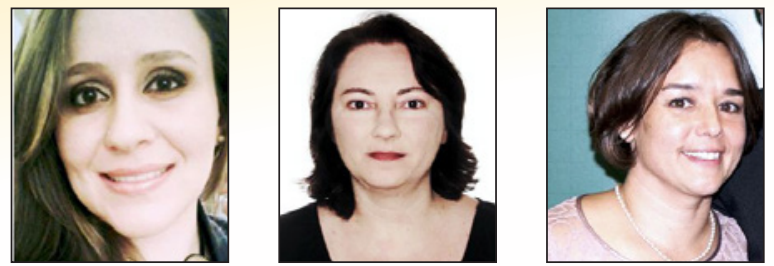

A. F. ANGELIN a andressa.angelin@pos.ft.unicamp.br

R. C. CECCHE LINTZ b rosacclintz@ft.unicamp.br

L. A. G. BARBOSA a gachet@ft.unicamp.br

\section{Abstract}

A produção de concretos auto compactáveis de baixa massa específica tornou-se um grande desafio para a engenharia civil, principalmente quanto à dosagem e manutenção das resistências mecânicas. Nesse contexto, o objetivo deste trabalho foi analisar concretos autoadensáveis (CAA) produzidos com agregados leves e reciclados. Fixou-se as dosagens de sílica ativa, pó de pedra, pedrisco, argila expandida e superplastificante, variando-se a porcentagem do resíduo de borracha em $5 \%$ e $10 \%$, em substituição ao agregado miúdo. As amostras foram submetidas aos ensaios de espalhamento, viscosidade, habilidade passante, resistências à compressão e à tração por compressão diametral e, massa específica. Verificou-se que os CAA produzidos apresentaram coesão e trabalhabilidade adequados, bem como atendem as condições normativas para uso em peças pré-moldadas e estruturais.

Keywords: self-compacting concrete, lighweight aggregate, reclycled aggregate, fresh properties, mechanical strengths.

\section{Resumo}

The production of self-compacting concrete (SCC) with low density has become a major challenge for civil engineering, especially regarding the dosage and maintenance of mechanical strength. In this context, the objective of this work was to analyze self-compacting concrete (SCC) using lightweight and recycled aggregates. Fixed the additions of silica fume, stone dust, gravel, expanded clay and superplasticizer, varying the percentage of rubber waste by $5 \%$ and $10 \%$, replacing the fine aggregate. The samples were subjected to spreading assays, viscosity, passing ability, compressive strength and tensile strength by diametrical compression and density. It was found that SCC produced had adequate cohesion and workability as well as meet the regulatory conditions for use in pre-cast and structural parts.

Palavras-chave: concreto autoadensável, agregado leve, agregado reciclado, propriedades no estado fresco, resistências mecânicas.

Technology Faculty, State University of Campinas, Limeira, SP, Brazil.

Received: 16 Apr 2016 • Accepted: 26 Oct 2016 • Available Online: 15 Feb 2018 


\section{Introduction}

The mechanization of the constructive processes, as a way to accelerate the production processes and, as a consequence, the productivity of prefabricated elements, has encouraged further studies of self-compacting lightweight concrete (SCLC), which is an alternative material to conventional concrete.

Lightweight concrete congregates low density and maintenance of mechanical resistances, can be applied for structural purposes, directly influencing the economy with infrastructure [1]. It should also be noted that, the use of this type of concrete results in a higher productivity than the conventional concrete, facilitating the transport of the pieces during the execution phase of the building.

As well as lightweight concrete, the self-compacting concrete (SCC) has emerged as an alternative to conventional. According to surveys already performed [2,3], the main attractiveness of its use is the ease of handling and application, whose ability to fill the existing spaces in the formwork and to enclose the reinforcement, is given exclusively through the action of gravity, without any mechanical or manual interference.

When we working with more fluid concretes, it has as consequence a reduction in the time of handling and densification when applied in prefabricated elements, causing in the greater productivity and lower final cost in the concreting operation.

The most important principles to maintain the characteristics of the SCC are the use of superplasticizers, mineral additions, high content of fine materials and mortar, resulting in a greater cohesion and fluidity of the paste, however, we have a concrete that absorbs less energy, that is, it becomes extremely sensitive to the presence of cracks and microcracks, compromising the integrity of the material $[4,5]$.

In order to minimize this effect, the rubberized concretes present better capacity to the damping, due to the significant increase of the toughness and ductility [6]. In addition to improving this property, the use of rubber in concrete appears as an alternative solution for the disposal of waste tires, being an innovative option with numerous benefits.

In the composition of SCC with light aggregates, mineral additions, usually derived from industrial byproducts, present great pozzolanic activity, which ensures greater cohesion between the components of this concrete [3]. However, given the high surface area of these additions, it is necessary to use superplasticizing additives in order to maximize the flowability of the $\mathrm{SCC}$ without compromising the water/cement ratio [7].

In this way, it is evident the merit of developing self-compacting concrete with light and recycled aggregates, being a modern study line and still little explored in the technical field. However, this type of concrete needs to meet specific requirements for its application, such as high fluidity, cohesion, resistance to segregation in the fresh state, low density and mechanical resistance.

\subsection{Self-compacting lightweight concrete (SCLC)}

The self-compacting lightweight concrete (SCLC) is characterized by high workability without segregation phenomena and high durability [8]. The success for the production of this concrete is the use of light aggregates, such as expanded clay, obtained through the expansion of clay and its vitrification in rotary kilns.

The use of expanded clay as an aggregate in SCC, coupled with mineral additions, mainly silica fume, may result in a highly viable and durable concrete $[1,8,9,10]$. The use of these aggregates has contributed to sustainable development through energy conservation, maximizing the structural efficiency and shelf life of precast elements, reducing transport costs due to their low density [4]. However, as already observed in other studies [1, 4], there is a loss of working capacity associated with high water absorption by light aggregates, directly influencing SCC properties, especially in the fresh state. Therefore, pre-saturation of these aggregates must be performed in order to solve this problem, most commonly the water immersion method, performed by a period of 24 hours prior to the production of the concretes.

The use of expanded clay, mainly of larger dimension, in the SCC, causes a greater bearing between the particles during the tests in the fresh state, due to rounded form and glassy surface, in comparison with conventional aggregates [1, 8, 9, 10, 11]. In addition, self-compacting concrete incorporating round-shaped aggregates requires less cement and water to achieve adequate workability and cohesion of their mixtures [11].

Another important characteristic in the formulation of SCC is the granulometric distribution of its aggregates. Some authors point out in their works the use of two expanded clay granulometry, so that fluidity and scattering are improved by better packing the grains, filling the voids $[1,8]$.

Recent studies $[8,11]$ have added silica fume in self-compacting concrete mixtures and, due to their micrometric size, provide a very high cohesion and fluidity increase in this type of concrete, especially when using special aggregates such as expanded clay.

These benefits emphasize the importance of developing projects with the use of SCLC, since, besides presenting the main characteristics of the self-compacting concrete, such as fluidity and workability, they have excellent resistance to segregation, low density, maintenance of the mechanical properties and durability in the hardened state.

\subsection{Self-compacting rubberized concrete (SCRC)}

An alternative solution for the disposal of waste tires is its incorporation in concrete mixtures, since it is an innovative option with environmental, economic and performance benefits, performed in granulometry and adequate percentages [7].

The tires that have the carcass in good condition can be refurbished and reused. According to CONAMA Resolution 416/2009 [12], the reform processes can be characterized by reuptake, a process by which the used tire is reformed by replacing its tread; retreading, the process by which a used tire is reformed by replacing its tread and shoulders; remolding, the process by which a used tire is reformed by replacing its tread, shoulders and the entire surface of its flanks. In the reuptake and retreading, by scraping the layer to be reformed, residues are generated in the form of fibers and rubber powder, granulometries widely used in cementitious matrix as an aggregate [13]. 
In the recycling process, the unserviceable tire is crushed and reduced into smaller particles. The grinding can be done at room temperature or by the cryogenic process. At room temperature the tires are first processed into $50 \mathrm{~mm}$ flakes, then these flakes go to the crusher and are reduced to $10 \mathrm{~mm}$, in which process part of the steel is removed and after the crusher the remainder of the steel is magnetically removed [14].

Although there is a demand for $10 \mathrm{~mm}$ crushed rubber, most applications in construction require finer grades in the range of 2 to $0.84 \mathrm{~mm}$. For this reason, are perform consecutive crushing in the milling companies [14].

The presence of rubber as an aggregate reduces some mechanical properties of the concrete, so percentages above $30 \%$ of substitutions are not recommended [15]. This resistance drop occurs due to the weak bonding between the rubber particle and the cement matrix and also by the rough granulometry of the rubber [2, 3].

Besides the limits of substitutions of the conventional aggregates for the rubber residue, another important aspect in the formulation of the self-compacting rubberized concrete is the granulometric distribution $[3,16]$. As observed in SCC with expanded clay, from the use of large and small granulometry, there is a better packaging of the grains, filling the voids, increasing the durability of the concrete. After the addition of rubber particles, studies have indicated a remarkable decrease in the stiffness and strength properties of the concretes. Despite the reduction of these properties, the composites met the normative requirements, besides showing a significant increase of the tenacity and ductility, as well as a better capacity of damping. In contrast, the use of this aggregate, significantly aggravates the penetration of chloride ions through concrete, however, from mineral additions, this effect can be reduced because the existing voids are filled [6].

SCRC requires a greater amount of superplasticizer in their mixtures when compared to self-compacting conventional concrete, because the rubber particles have a rough surface, which results in increased cohesion, but drastically decreases the workability [2]. Vibration damping coefficient values and frequency, given by the

Table 1

Materials characterization

\begin{tabular}{|c|c|c|c|c|c|c|}
\hline Component & Cement & Sand & Rubber & Stone powder & Hail & Expanded clay \\
\hline \multicolumn{7}{|c|}{ Chemical element (\%) } \\
\hline C & - & - & 91.50 & - & - & - \\
\hline Zn & - & - & 3.50 & - & - & - \\
\hline O & - & - & 3.30 & - & - & - \\
\hline$S$ & - & - & 1.20 & - & - & - \\
\hline $\mathrm{Na}$ & - & - & 0.20 & - & - & - \\
\hline $\mathrm{Ca}$ & - & - & 0.10 & - & - & - \\
\hline
\end{tabular}

\begin{tabular}{|c|c|c|c|c|c|c|}
\hline \multicolumn{7}{|c|}{ Chemical composition (\%) } \\
\hline $\mathrm{CaO}$ & 63.33 & - & - & - & - & - \\
\hline $\mathrm{SiO}_{2}$ & 19.19 & - & - & - & - & - \\
\hline $\mathrm{Al}_{2} \mathrm{O}_{3}$ & 5.15 & - & - & - & - & - \\
\hline $\mathrm{Fe}_{2} \mathrm{O}_{3}$ & 2.80 & - & - & - & - & - \\
\hline $\mathrm{MgO}$ & 0.92 & - & - & - & - & - \\
\hline L.O.I. & 3.97 & - & - & - & - & - \\
\hline I.R. & 0.48 & - & - & - & - & - \\
\hline
\end{tabular}

\begin{tabular}{|c|c|c|c|c|c|c|}
\hline \multicolumn{7}{|c|}{ Physical proprieties } \\
\hline $\begin{array}{c}\text { Density } \\
\left(\mathrm{g} \times \mathrm{cm}^{-3}\right)\end{array}$ & 3.11 & 2.63 & 1.14 & 2.76 & 2.96 & 1.15 \\
\hline $\begin{array}{c}\text { Unit mass } \\
\left(\mathrm{g} \times \mathrm{cm}^{-3}\right)\end{array}$ & - & 1.57 & 0.35 & 1.56 & 1.50 & 0.62 \\
\hline $\begin{array}{c}\text { Maximum } \\
\text { dimension } \\
(\mathrm{mm})\end{array}$ & - & 2.40 & 4.80 & 4.80 & 9.50 & 9.50 \\
\hline \multicolumn{7}{|l|}{ Fineness }
\end{tabular}


dynamic modulus, are of great importance in structural applications. Improving it means improving reliability in terms of natural hazards, accidental or hydrostatic loading, and fragmentation. Concretes produced with residues of waste tires have a delay in the appearance of microcracks in the matrix, reducing shrinkage rates, being able to absorb more energy than the conventional SCC $[5,13,14]$.

Recent studies, in order to compensate for the low values in some mechanical properties of the SCRC, performed a pretreatment of the rubber particles by water-soluble synthetic polymer solutions, which proved to be efficient as the mechanical results were improved [2, 3].

According to the results found in the literature [12], it was determined that the addition of the rubber aggregate in SCC increases the impact resistance, this increase being proportional to the added amount of rubber. Self-compacting rubberized concrete, as reported by several authors, absorbs more energy, isolating better the sound waves $[5,16,17]$. Therefore, SCRC can be applied to precast elements requiring high ductility, combining high fluidity and maintenance of mechanical stresses, characteristics that are not maintained in self-compacting conventional concretes.

Due to these aspects, the objective of this work was to study the performance of self-compacting concrete produced with expanded clay and rubber waste from unserviceable tires, from the retreading process. Mixtures with fixed dosages of silica fume, stone powder, hail, expanded clay and superplasticizer were elaborated, the percentage of the rubber residue being varied by $5 \%$ and $10 \%$, replacing the sand. The mixtures were submitted, in the fresh state, to the scattering, viscosity and pass ability tests. In the hardened state were performed the tests of compressive and tensile strength, as well as the density.

\section{Materials and experimental program}

To achieve the objectives of this work, the materials for the preparation of the concretes were selected, which were characterized before the calculation and the production of the mixtures. After their production, the concretes were submitted to the tests in the fresh state and, after the curing process, to the mechanical and density tests. These procedures were followed by normative recommendations and were performed in the Construction Materials Laboratory of the Faculty of Technology of the State University of Campinas.

\subsection{Materials}

Was used Portland cement with high initial resistance, which guarantees high resistances with greater speed and, silica fume that guarantees greater cohesion to the mixtures. As a natural aggregate, fine quartz sand was used and, as its partial substitute, was used the rubber residue of unserviceable tires, from the retreading process. As a thin material, the stone powder was adopted, which has the purpose of increasing the fluidity of the mixtures. Hail and expanded clay were used as large aggregates. A plasticizer based on polycarboxylic ether was used to ensure workability in concrete mixtures. The characterization of cement, sand, rubber, stone powder, hail and expanded clay are presented in Table 1. Fig. 1 shows the grain size curve of sand and rubber.

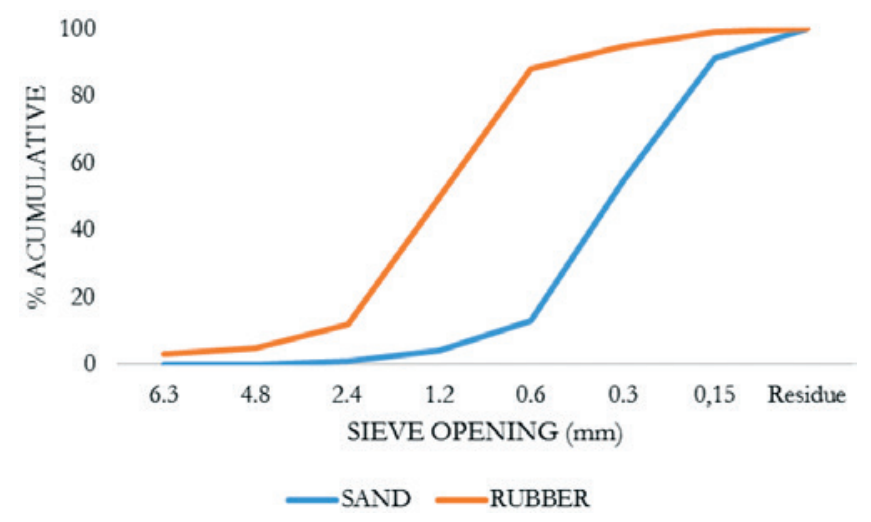

Figure 1

Granulometric curve of sand and rubber

The superplasticizer used exhibited density of $1.19 \mathrm{~g} \mathrm{x} \mathrm{cm}^{-3}, \mathrm{pH}$ $=6$, solids content of $30 \%$ and viscosity of less than $150 \mathrm{cps}$, while the silica fume had a density of $2.21 \mathrm{~g} \mathrm{x} \mathrm{cm}^{-3}$. In order to understand the absorption process of the expanded clay, the water absorption test was performed and the results are presented in Table 2.

\subsection{Dosage and production of concretes}

Concrete mixtures were prepared incorporating $0 \%, 5 \%$ and $10 \%$ of rubber residue, replacing the small aggregate, following the recommendations proposed by $\mathrm{ACl} 211.2-98$ [18] and by Tutikian [19]. The dosages were performed with the purpose of guaranteeing workability values around $560 \mathrm{~mm}(+/-10 \mathrm{~mm})$, density around $2,000 \mathrm{~kg} / \mathrm{m}^{3}$ and compressive strength above $20 \mathrm{MPa}$ at 28 days of age. The water/cement ratio used for all mixtures was 0.68 . The sample identifications were $C R$ for the reference mixture, and $\mathrm{C} 5$ and $\mathrm{C} 10$ for the mixtures containing $5 \%$ and $10 \%$ rubber residue, respectively. The mixtures are shown in Table 3.

Because of the high absorption, the expanded clay remained immersed in water for 24 hours, before to the production of the concretes. As observed in Table 2 and reported by other authors [1,

\section{Table 2}

Expanded clay water absorption

\begin{tabular}{|c|c|}
\hline \multirow{2}{*}{ Time } & Water absorption (\%) \\
\cline { 2 - 2 } & CINEXPAN 1506 \\
\hline 1 min & 0.67 \\
\hline 5 & 1.50 \\
\hline 10 & 2.00 \\
\hline 30 & 3.10 \\
\hline 1 hour & 3.83 \\
\hline 2 & 4.33 \\
\hline 6 & 5.50 \\
\hline 1 day & 7.50 \\
\hline
\end{tabular}


Table 3

Materials characterization

\begin{tabular}{|c|c|c|c|c|c|c|c|c|c|c|}
\hline Mixtures & Cement & $\begin{array}{l}\text { Silica } \\
\text { fume }\end{array}$ & Sand & Rubber & $\begin{array}{l}\text { Stone } \\
\text { powder }\end{array}$ & Hail & C1506 & SPA & $w / c$ & $\begin{array}{c}\text { Mortar } \\
\text { content } \\
(\%)\end{array}$ \\
\hline $\mathrm{CR}$ & \multirow{3}{*}{1} & \multirow{3}{*}{0.1} & 1.81 & 0 & \multirow{3}{*}{1.56} & \multirow{3}{*}{1.95} & \multirow{3}{*}{0.02} & 0.008 & \multirow{3}{*}{0.68} & \multirow{3}{*}{0.69} \\
\hline C5 & & & 1.77 & 0.04 & & & & 0.008 & & \\
\hline $\mathrm{C} 10$ & & & 1.73 & 0.08 & & & & 0.008 & & \\
\hline
\end{tabular}

4], because it is a porous material, the expanded clay can compromise the amount of water available for the hydration of the cement, and, to compensate this effect, the previous wetting procedure of this material is recommended.

It was mixed in a concrete mixer, previously moistened, the hail and expanded clay (1 minute), then water and the Portland cement ( 3 minutes), followed by stone powder, sand and silica fume (3 minutes). After that, the superplasticizer was introduced and, a new mixture occurred for 3 minutes. The production process of the mixtures $\mathrm{C} 5$ and $\mathrm{C} 10$ occurred analogous to that used for the reference concrete, however, the rubber was introduced after the sand.

The samples were placed in molds and covered by a polymer film in order to avoid loss of water to the medium. After 24 $\mathrm{h}$ the samples were deformed and subjected to wet curing (Temperature $=25^{\circ} \mathrm{C}$ and Relative Humidity $=80 \%$ ) for a period of 7 and 28 days, for later performance of the tests in the hardened state.

\subsection{Tests in the fresh state}

The tests realized to characterize the self-compacting determine directly and indirectly the fundamental rheological parameters of the concrete, such as drainage tension and viscosity. According to ABNT NBR 15823: 2010 [20], three main parameters should be characterized in the SCC, which are:

a) Flowability - Scattering test: the scattering value measured by the slump flow test is specified for all SCC as a primary test, sketching indications of flowability and filling ability of free flowing. The fluidity is defined as the ability of the concrete to flow freely without segregating. The equipment used is the same one adopted in the test of determination of the consistency for the conventional concrete, the cone mold. The densification of the concrete inside the mold, properly positioned on the center of a flat base, is given exclusively by the force of gravity. After filling, the mold is lifted and the concrete flows freely. The test result is the average of two perpendicular diameters of the circle formed by the concrete mass.

b) Apparent plastic viscosity - "V" funnel test: viscosity is a property related to its consistency in the fresh state and influences its resistance to flow. The greater the viscosity of the concrete, the greater its resistance to the flow, causing its displacement inside the form to occur more slowly. ABNT NBR 15823:2010 [20] specifies a qualitative evaluation of the viscosity of the concrete by means of the SCC flow time in tests that measure its ability to flow and is therefore called apparent plastic viscosity. As well as the slump flow test, the "V" funnel test also serves as a measure of the fluidity of the concrete, which involves a qualitative evaluation of the apparent viscosity of the concrete, in confined flow, from the time record that the concrete takes to drain on this equipment. This measure consists of timing the time the concrete takes to drain completely through a V-shaped rig.

c) Passing ability - "L" box test: this property informs about the ability of fresh concrete to flow, without losing uniformity or causing blockage through confined spaces and narrow openings, such as areas of high density of reinforcement and sausages. The test using the "L" box, provided in part 4 of ABNT NBR 15823:2010 [20], measures the passing ability, under confined flow, by means of the ratio between the heights $\mathrm{H} 2$ and $\mathrm{H} 1$ of the concrete surface at the two extremities of the horizontal box, after opening the partition grid between the compartments. The ABNT NBR 15823: 2010 [20] classifies the SCC in the fresh state according to the presented parameters and, it recommends the correlation of this classification with the application of the concrete in the field, as exemplified in Table 4.

According to the normative requirements, the test procedures for the acceptance of the SCC in the fresh state shall be based, as a minimum, on the proof of the fluidity and viscosity properties as evaluated by the spreading test for each concrete. This standard also emphasizes that its procedures apply to concrete with a normal density (from 2,000 to 2,800 $\mathrm{kg} / \mathrm{m}^{3}$ ), and that the applicability of the requirements established for the SCC with intentional inclusion of air, light aggregates, heavy aggregates and fibers. In view of the above, it can be concluded that the parameters cannot be considered in isolation, because all properties in the fresh state are interdependent.

\subsection{Tests in the hardness state}

The density values were determined according to the requirements of ABNT NBR 9778: 2009 [21], for concrete with 28 days of age, using specimens with $100 \mathrm{~mm}$ diameter and $200 \mathrm{~mm}$ height. Three samples were cast for each concrete mix developed. This test was performed at the Civil Construction Materials Laboratory of UNICAMP's Faculty of Technology, following the steps below:

a) immersion of the samples in water at $20^{\circ} \mathrm{C}$ and measurements on a hydrostatic balance $\left(\mathrm{m}_{\mathrm{i}}\right)$; 
b) the samples were then dried in an oven at $105{ }^{\circ} \mathrm{C}$ and, after removal of the greenhouse, the samples were cooled to room temperature for subsequent determination of the dry mass in the oven $\left(\mathrm{m}_{\mathrm{s}}\right)$.

After obtaining the masses mentioned above, it was possible to calculate the density of the samples by means of the following equation:

Density $=m_{s} / m_{s}-m_{i}$

The compressive and tensile strengths of the concretes were determined according to the requirements of ABNT NBR 5739:
2007 [22] and ABNT NBR 7222: 2011 [23], respectively. Cylindrical specimens with $100 \mathrm{~mm}$ diameter and $200 \mathrm{~mm}$ height were used at the ages of 7 and 28 days. For each dosage, ten samples were molded to be compression, and six samples were tested for tensile. The tests were performed in the Civil Construction Materials Laboratory of UNICAMP's Faculty of Technology.

\section{Results and discussions}

\subsection{Tests in the fresh state}

The tests of fluidity, viscosity and passing ability were performed

\section{Table 4}

Classes of spreading, apparent plastic viscosity and passing ability of the SCC depending on its application

\begin{tabular}{|c|c|c|c|}
\hline Properties & Classes & Application & Example \\
\hline $\begin{array}{c}\text { Spreading (slump-flow) } \\
(\mathrm{mm})\end{array}$ & SF 1:550 to 650 & $\begin{array}{c}\text { Unarmed or low armature structures } \\
\text { and embedded structures, whose } \\
\text { concreting is realized from the } \\
\text { highest point with free displacement; } \\
\text { Self-compacting concrete pumped; } \\
\text { Structures requiring a short horizontal } \\
\text { spread of self-compacting concrete. }\end{array}$ & $\begin{array}{c}\text { Slab, lining of tunnels, } \\
\text { stakes certain deep } \\
\text { foundations. }\end{array}$ \\
\hline $\begin{array}{c}\text { Spreading (slump-flow) } \\
(\mathrm{mm})\end{array}$ & SF 2: 660 to 750 & $\begin{array}{c}\text { Suitable for most current } \\
\text { applications. }\end{array}$ & $\begin{array}{c}\text { Walls, beams, } \\
\text { pillars and others. }\end{array}$ \\
\hline $\begin{array}{c}\text { Spreading (slump-flow) } \\
(\mathrm{mm})\end{array}$ & SF 3: 760 to 850 & $\begin{array}{c}\text { Structures with high density of } \\
\text { reinforcement and/or of complex } \\
\text { architectural form, with the use of } \\
\text { concrete with small aggregate of } \\
\text { small dimensions (less than 12.5 mm). }\end{array}$ & $\begin{array}{c}\text { Wall-pillars, diaphragm } \\
\text { walls and pillars. }\end{array}$ \\
\hline
\end{tabular}

\begin{tabular}{|c|c|c|c|}
\hline Properties & Classes & Application & Example \\
\hline $\begin{array}{c}\text { Apparent plastic viscosity } \\
\text { ("V" Funnel) (s) }\end{array}$ & VF $1:<$ or $=8$ & $\begin{array}{l}\text { Suitable for structural elements } \\
\text { with high density of armature and } \\
\text { embedded, but requires control of } \\
\text { exudation and segregation; } \\
\text { Concretes made from the highest } \\
\text { point with free displacement. }\end{array}$ & $\begin{array}{l}\text { Slabs, diaphragm } \\
\text { walls, wall-pillars, } \\
\text { precast industry and } \\
\text { apparent concrete. }\end{array}$ \\
\hline $\begin{array}{c}\text { Apparent plastic viscosity } \\
\text { ("V" Funnel) (s) }\end{array}$ & VF $2: 9$ to 25 & $\begin{array}{l}\text { Suitable for most current applications; } \\
\text { It presents a thixotropic effect that } \\
\text { causes less pressure on the forms and } \\
\text { better resistance to segregation; } \\
\text { Negative effects can be obtained } \\
\text { in relation to the finishing surface } \\
\text { (trapped air), in the filling of corners } \\
\text { and susceptibility to interruptions or } \\
\text { delay between successive layers. }\end{array}$ & Beams, pillars and others. \\
\hline
\end{tabular}

\begin{tabular}{|c|c|c|c|}
\hline Properties & Classes & Application & Example \\
\hline $\begin{array}{c}\text { Passing ability ("L" Box) } \\
\text { (H2/H1) }\end{array}$ & $\begin{array}{l}\text { PJ } 1:>\text { or }=0,80 \\
\text { with } 3 \text { steel bars }\end{array}$ & $\begin{array}{l}\text { Suitable for structural elements with } \\
\text { reinforcement spacing from } \\
80 \text { to } 100 \mathrm{~mm} \text {; } \\
\text { Suitable for most current } \\
\text { applications. }\end{array}$ & $\begin{array}{c}\text { Slabs, panels, foundations, } \\
\text { beams, pillars, tie rods, } \\
\text { precast industry. }\end{array}$ \\
\hline
\end{tabular}


Table 5

Results of the tests in the fresh state

\begin{tabular}{|c|c|c|c|c|c|c|}
\hline Mixtures & $\begin{array}{l}\text { Slump } \\
\text { flow test } \\
(\mathrm{mm})\end{array}$ & $\begin{array}{l}\text { Minimum } \\
\text { required by } \\
\text { the Brazilian } \\
\text { standard }\end{array}$ & $\begin{array}{c}\text { "L" box } \\
\text { (H2/H1) }\end{array}$ & $\begin{array}{l}\text { Minimum } \\
\text { required by } \\
\text { the Brazilian } \\
\text { standard }\end{array}$ & $\begin{array}{l}\text { "V" funnel } \\
\text { (s) }\end{array}$ & $\begin{array}{l}\text { Minimum } \\
\text { required by } \\
\text { the Brazilian } \\
\text { standard }\end{array}$ \\
\hline CR & 570 & \multirow{3}{*}{$>550$} & 1.00 & \multirow{3}{*}{$>0.80$} & 4 & \multirow{3}{*}{$<8$} \\
\hline C5 & 550 & & 0.85 & & 5 & \\
\hline $\mathrm{C} 10$ & 550 & & 0.80 & & 7 & \\
\hline
\end{tabular}

for the concretes produced in this research, and the results were compared with the values specified by the current Brazilian standard [20]. Table 5 shows the results of the fresh state tests of SCC produced with expanded clay and waste rubber from waste tires. It was observed for all mixtures that the slump flow test reached the level of self-adherence specified for class SF1 and could be used in slabs, lining of tunnels, piles and foundations. The CR showed higher fluidity, guaranteed by the use of expanded clay, than $C 5$ and $C 10$, that is, the rubber residue increases the flow stress in the concrete. This occurs due to the rough and non-stick surface of the rubber, which corroborates to a decrease in the spreading of the mixtures [2, 3, 6]. However, due to the adequate proportion of materials and particle size distributions, the cohesion of all the mixtures was maintained, which did not present the segregation phenomenon of its aggregates.

The measures found in the "L" box, which simulates the ability of fresh concrete to flow through confined and narrow spaces, qualify the concrete as being class PJ1, in equipment consisting of 3 steel bars. This class of SCC is suitable for use in structural elements with spacing between reinforcements from 80 to $100 \mathrm{~mm}$. Their applications can occur in panels, beams, pillars, tie rods, among other precast elements.

The results obtained in the test using the funnel " $\mathrm{V}$ ", all concretes were classified as VF1, because they had a flow time of less than 8 seconds; that is, it is suitable for use in structural elements with high density of reinforcement, however, it is required a control of the



Figure 2

Compressive strength, with respect to the cure time exudation and segregation of its aggregates. It was observed that the reference trace had lower viscosity, that is, the flow time at funnel "V" was lower. In contrast, the mixtures C5 and C10 exhibited higher viscosity due to the increase of the rubber in the mixtures.

From the results obtained in the tests in the fresh state, it was observed that the use of the expanded clay as a large aggregate causes a greater rolling effect in the concrete, guaranteeing the desired fluidity. This occurs due to the rounded shape and glassy surface of the expanded clay, compared to conventional large aggregates, a fact also observed by other authors [1, 8-11]. In addition, the use of silica fume in the mixtures has been found to provide adequate cohesion. This is due to the micrometric size and the high pozzolanic activity of the mineral addition used, which corroborate the stability of the aggregates in the SCC, ensuring that the segregation phenomenon does not occur $[8,11,24]$.

\subsection{Tests in the hardness state}

The values of the compressive strength are shown in Fig. 2. All the mixtures presented, at 7 and 28 days, compressive strength values greater than $20 \mathrm{MPa}$, the minimum value required by ABNT NBR 6118: 2014 [25] for structural concretes, which is attributed mainly to the use of silica fume that presents high pozzolanic activity, contributing to the maintenance of mechanical resistance in cementitious matrixes $[9,10]$.

From the results observed in Fig. 2, it was noted that there was a decrease in compressive strength of the CR to the C5 of approximately $23 \%$. Contrary to what was observed in the CR and C5 mixtures, there was an increase in the compressive strength of $\mathrm{C} 5$ to C10 around $15 \%$. This phenomenon demonstrates that there was a better packaging of the rubber residue when the substitution was $10 \%$, that is, in the substitution of $5 \%$, the rubber does not distribute with uniformity in the concrete, causing the resistance drop due to the low value of modulus of elasticity of the polymer aggregate and voids caused by the entrainment of air, which are not filled [26, 27]. When the rubber is evenly distributed, there is also a uniform absorption of mechanical energy in the concrete, thus increasing the compressive strength; however, when there is an excessive addition of rubber, its particles become the least resistant point of the concrete, because it has a weak bond with the cement matrix due to its coarse and non-stick granulometry [3, 26, 27].

The tensile compression strength values, at 7 and 28 days of age, are shown in Fig. 3. As observed in the compressive strength test, the values obtained for the tensile compression showed a decrease of the CR for The C5 around 33\% and an increase of 


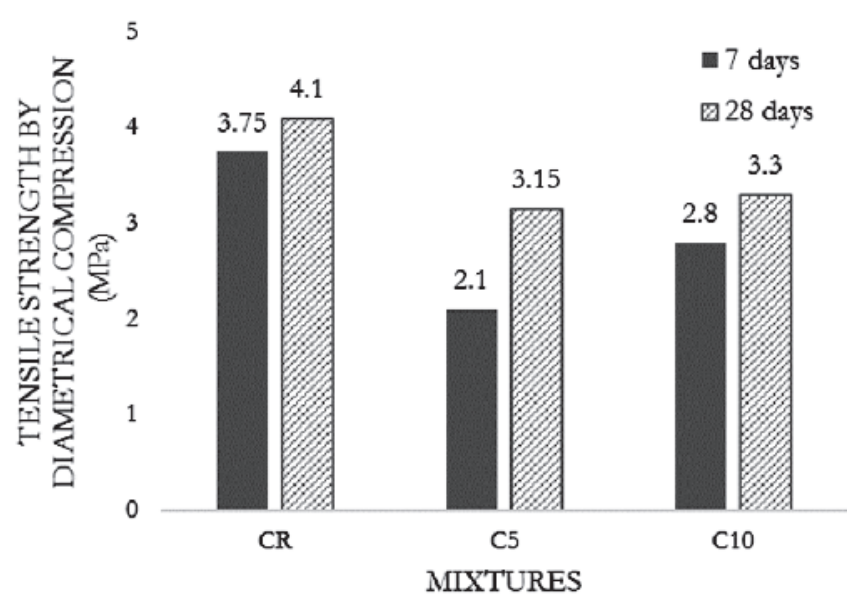

\section{Figure 3}

Tensile strength by diametrical compression, with respect to the cure time

$19 \%$ from $\mathrm{C} 5$ to $\mathrm{C} 10$. Some researchers $[3,13]$ also observed that for smaller rubber granulometries mechanical strength tends to increase compared to larger granulometries due to better distribution of aggregates and filling of concrete pores, significantly improving the quality of the transition zone.

In order to classify the concretes produced as lightweight, the density test was performed, the values of which are shown in Fig. 4. From the presented values it can be observed that there is a decrease in the concrete mass of the concretes as the quantity increases of rubber in the mixtures, this occurs due to the low density and the formation of a film of air around the rubber [3, 28, 29]. However, none of the mixtures can be classified as lightweight concrete, since, according to ABNT NBR 8953: 2015 [30], this value must be equal to or less than $2,000 \mathrm{~kg} / \mathrm{m}^{3}$. In spite of presenting smaller specific masses than conventional aggregates, the amount of expanded clay and rubber used in this research did not contribute to the production of light parts according to the normative prescriptions.

\section{Conclusions}

The methodology used for the dosing of the concretes was efficient,

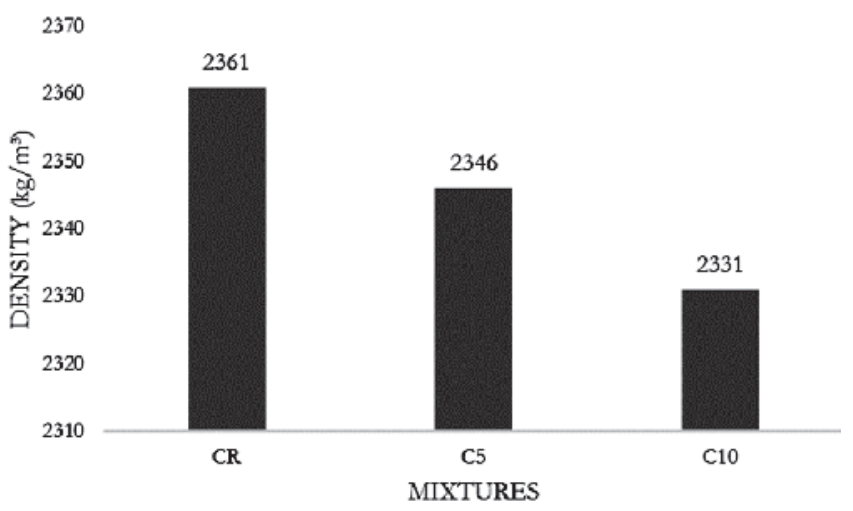

Figure 4

Density at 28 days not presenting the phenomena of segregation and exudation;

- All mixtures have adequate cohesion and consistency for handling and molding, as well as maintaining workability;

- According to the results obtained in the fresh state tests, all concretes produced in this research can be characterized as self-compacting;

- There was a decrease of mechanical resistance of the $C R$ to the $\mathrm{C} 5$, however, there was an increase of the $\mathrm{C} 5$ to the $\mathrm{C} 10$;

- For the mixtures developed in this research, the best packaging of the rubber grains occurred in the trait $\mathrm{C} 10$, because they presented better values of mechanical resistance;

- As for the density values, all the traces had values above 2,000 $\mathrm{kg} / \mathrm{m}^{3}$, that is, the concretes produced cannot be characterized as light.

\section{Acknowledgment}

The authors are grateful to CAPES for the scholarship granted and the companies Cinexpan, Tecnosil and Basf for the materials donated to realization this research.

\section{References}

[1] BOgAS, J. A.; GOMES, A.; PEREIRA, M. F. C. Self-compacting lightweight concrete produced with expanded clay aggregate. Construction and Building Materials, v. 35, p. 1013-1022, 2012.

[2] KARAHAN, O. et al. Fresh, Mechanical, Transport and Durability Properties of Self-Consolidating Rubberized Concrete. ACI Materials Journal, v. 109, 2013.

[3] YUNG, W. H.; YUNG, L. C.; HUA, L. H. A study of the durability properties of waste tire rubber applied to self-compacting concrete. Construction and Building Materials, v. 41, p. 665672, 2013.

[4] KWASNY, J. et al. Influence of the Type of Coarse Lightweight Aggregate on Properties of Semi-Lightweight SelfConsolidating Concrete. Journal of Materials in Civil Engineering, December, p. 455, 2012.

[5] RAHMAN, M. M.; USMAN, M.; AL-GHALIB, A. A. Fundamental properties of rubber modified self-compacting concrete (RMSCC). Construction and Building Materials, v. 36, p. 630-637, 2012.

[6] GESOLU, M.; GUNEYISI, E. Permeability properties of selfcompacting rubberized concretes. Construction and Building Materials, v. 25, n. 8, p. 3319-3326, 2011.

[7] RAJ, B.; GANESAN, N.; SHASHIKALA, A. P. Engineering properties of self-compacting rubberized concrete. Journal of Reinforced Plastics and Composites, v. 30, n. 23, p. 19231930, 2011.

[8] LOTFY, A.; HOSSAIN, K. M. A.; LACHEMI, M. Lightweight Self-consolidating Concrete with Expanded Shale Aggregates: Modelling and Optimization. International Journal of Concrete Structures and Materials, v. 9, n. 2, p. 185-206, 2015.

[9] JURADIN, S.; BALOEVI, G.; HARAPIN, A. Experimental testing of the effects of fine particles on the properties of the self-compacting lightweight concrete. Advances in Materials Science and Engineering, 2012. 
[10] GOPI, R. et al. Light expanded clay aggregate and fly ash aggregate as self-curing agents in self-compacting concrete. Asian Journal of Civil Engineering, v. 16, n. 7, p. 1025-1035, 2015.

[11] GESOGLU, M. et al. Shear thickening intensity of self-compacting concretes containing rounded lightweight aggregates. Construction and Building Materials, v. 79 , p. $40-47$, 2015.

[12] RESOLUÇÃO CONAMA 416 de 30 de Setembro de 2009. Disponível em: http://www.mma.gov.br/port/conama/legiabre.cfm?codlegi=616, acesso em 20 de agosto de 2016 .

[13] LAGARINHOS, C. A. F.; TENÓRIO, J. A. S.; Tecnologias Utilizadas para a Reutilização, Reciclagem e Valorização Energética de Pneus no Brasil, Ciência e Tecnologia, v. 18, $n^{\circ} 2$, p. 106-118, 2008.

[14] RESCHNER, K. Scrap Tire Recycling - A Summary of Prevalent Disposal and Recycling Methods, Berlim - Alemanha, 2008. Disponível em: http://www.entire-engineering.de/, acesso em 20 de agosto de 2016.

[15] KHALIL, E.; ABD-ELMOHSEN, M.; ANWAR, A. M. Impact Resistance of Rubberized Self-Compacting Concrete. Water Science, v. 29, n. 1, p. 45-53, 2015.

[16] NAJIM, K. B.; HALL, M. R. Mechanical and dynamic properties of self-compacting crumb rubber modified concrete. Construction and Building Materials, v. 27, n. 1, p. 521-530, 2012.

[17] GANESAN, N.; BHARATI RAJ, J.; SHASHIKALA, A. P. Flexural fatigue behavior of self-compacting rubberized concrete. Construction and Building Materials, v. 44, p. 7-14, 2013.

[18] AMERICAN CONCRETE INSTITUTE - ACI. Standard practice for selecting proportions for structural lightweight concrete- ACl 211.2-98, 2004.

[19] TUTIKIAN, B. F. Método para dosagem de concretos autoadensáveis. Dissertação. Universidade Federal do Rio Grande do Sul. Porto Alegre, 2004.

[20] ASSOCIAÇÃO BRASILEIRA DE NORMAS TÉCNICAS. NBR 15823: Requisitos para classificação, controle e aceitação do CAA no estado fresco. Rio de Janeiro, 2010.

[21] ASSOCIAÇÃO BRASILEIRA DE NORMAS TÉCNICAS. NBR 9778: Concreto - Determinação da absorção de água, índice de vazios e massa específica. Rio de Janeiro, 2009.

[22] ASSOCIAÇÃO BRASILEIRA DE NORMAS TÉCNICAS. NBR 5739: Concreto - Ensaios de compressão de corposde-prova cilíndricos. Rio de Janeiro, 2007.

[23] ASSOCIAÇÃO BRASILEIRA DE NORMAS TÉCNICAS. NBR 7222: Argamassa e concreto - Determinação da resistência à tração por compressão diametral de corpos-deprova cilíndricos. Rio de Janeiro, 2011.

[24] GUNEYISI, E.; GESOGLU, M.; BOOYA, E. Fresh properties of self-compacting cold bonded fly ash lightweight aggregate concrete with different mineral admixtures. Materials and Structures, v. 74, p. 17-24, 2015.

[25] ASSOCIAÇÃO BRASILEIRA DE NORMAS TÉCNICAS. NBR 6118: Projeto de estruturas de concreto - Procedimento. Rio de Janeiro, 2007.

[26] SILVA, F. M.; GACHET BARBOSA, L. A.; LINTZ, R. C. C.; JACINTHO, A. E. P.G. A. Investigation on the properties of concrete tactile paving blocks made with recycled tire rubber. Construction \& Building Materials, v. 91, p. 71-79, 2015.

[27] ANGELIN, A. F.; ANDRADE, M. F. F.; BONATTI, R.; CECCHE LINTZ, R. C.; GACHET-BARBOSA, L. A.; OSÓRIO, W. R. Effects of spheroid and fiber-like waste-tire rubbers on interrelation of strength-to-porosity in rubberized cement and mortars. Construction \& Building Materials, v. 95, p. 525-536, 2015.

[28] ASSOCIAÇÃO BRASILEIRA DE NORMAS TÉCNICAS. NBR 8953: Concreto para fins estruturais - Classificação pela massa específica, por grupos de resistência e consistência. Rio de Janeiro, 2015. 